Dhaka Univ. J. Sci. 60(2): 203-207, 2012 (July)

\title{
Utilization of Karanja (Pongamia pinnata) as a Major Raw Material for the Production of Biodiesel
}

\author{
Hossain Mohammad Imran ${ }^{1}$, Arafat H.Khan ${ }^{1}$, M.Shahinul Islam ${ }^{1}$, Niher R. S. ${ }^{1}$, Asaduzzaman Sujan ${ }^{2}$ and \\ A.M.Sarwaruddin Chowdhury ${ }^{1}$ \\ ${ }^{1}$ Department of Applied Chemistry and Chemical Engineering, University of Dhaka, Dhaka-1000, Bangladesh \\ ${ }^{2}$ Institute of Fuel Research and Development, Bangladesh Council of Scientific \& Industrial Research, Dhaka-1205, \\ Bangladesh
}

Received on 29. 06. 2011. Accepted for Publication on 19. 03. 2012.

\begin{abstract}
An experimental process for the production of biodiesel using karanja (Pongamia pinnata) seeds as a raw material has been studied. This process involved transesterification of karanja oil with methanol in the presence of a catalyst $(\mathrm{NaOH})$, to yield biodiesel as the main product and glycerin as by-product. In this research work, free fatty acid (FFA) of Karanja oil was determined and it was found less than 5\%. As a result, one step transesterification was carried out. Oil to methanol molar ratio (6:1 to 12:1), variation (0.5\% to $1.6 \%$ wt of oil) of Catalyst $(\mathrm{NaOH})$ concentration was determined. Base-catalyzed transesterification converted karanja oil into biodiesel and glycerol using $1 \% \mathrm{NaOH}$ as alkaline catalyst at $60-65^{\circ} \mathrm{C}$. This study revealed the maximum yield of biodiesel up to $85 \%$ with methanol to oil ratio $1: 9$ and for $1.5 \mathrm{hr}$ reaction at $65^{\circ} \mathrm{C}$. Co-ignition of biodiesel with commercial diesel was also evaluated and it was found that diesel engine run smoothly in the ratio of commercial diesel to biodiesel was 7:3.
\end{abstract}

Key words: Biodiesel, Karanja oil, Transesterification, Glycerin, Engine performance.

\section{Introduction}

Biodiesel has become more attractive recently because of its environmental benefits and the fact that it is made from renewable resources [1]. The American Society for Testing and Materials (ASTM) defines biodiesel fuel as mono alkyl esters of long chain fatty acids derived from a renewable lipid feedstock, such as vegetable oil or animal fat. "Bio" represents its renewable and biological source in contrast to traditional petroleum-based diesel fuel; "diesel" refers to its use in diesel engines. As an alternative fuel, biodiesel can be used in neat form or mixed with petroleum-based diesel. Biodiesel, as an alternative fuel, has many merits. It is derived from a renewable, domestic resource, thereby relieving reliance on petroleum fuel imports. It is biodegradable and nontoxic. Compared to petroleum-based diesel, biodiesel has a more favorable combustion emission profile, such as low emissions of carbon monoxide, particulate matter and unburned hydrocarbons. Carbon dioxide produced by combustion of biodiesel can be recycled by photosynthesis, thereby minimizing the impact of biodiesel combustion on the greenhouse effect [3][9]. Biodiesel has a relatively high flash point $\left(150^{\circ} \mathrm{C}\right)$, which makes it less volatile and safer to transport or handle than petroleum diesel [10]. It provides lubricating properties that can reduce engine wear and extend engine life [16]. In brief, these merits of biodiesel make it a good alternative to petroleum based fuel and have led to its use in many countries, especially in environmentally sensitive areas. The most common way to produce biodiesel is transesterification [4][5], which refers to a catalyzed chemical reaction involving vegetable oil and an alcohol to yield fatty acid alkyl esters (i.e., biodiesel) and glycerol . Triacylglycerols (triglycerides), as the main component of vegetable oil, consist of three long chain fatty acids esterified to a glycerol backbone. When triacylglycerols react with an alcohol (e.g., methanol), the three fatty acid chains are released from the glycerol skeleton and combine with the alcohol to yield fatty acid alkyl esters [7][8]. Glycerol is produced as a by-product. Methanol is the most commonly used alcohol because of its low cost and is the alcohol of choice in the processes developed in this study. In general, a large excess of methanol is used to shift the equilibrium far to the right. Transesterification reactions can be alkali-catalyzed, acidcatalyzed or enzyme-catalyzed. The first two types have received the greatest attention and are the focus of this article. As for the enzyme-catalyzed system, it requires a much longer reaction time than the other two systems [12][17]. To date it has only been carried out on the laboratory scale and therefore will not be further discussed herein. At present, the high cost of biodiesel is the major obstacle to its commercialization. Biodiesel usually costs over US $\$ 0.5 / 1$, compared to US $\$ 0.35 / 1$ for petroleum based diesel [13]. It is reported that the high cost of biodiesel is mainly due to the cost of virgin vegetable oil [10][6]. Exploring ways to reduce the high cost of biodiesel is of much interest in recent biodiesel research, especially for those methods concentrating on minimizing the raw material cost. The use of non edible karanja seed oil instead of virgin 
oil to produce biodiesel is an effective way to reduce the raw material cost because it is estimated to be about half the price of virgin oil [15]. In addition, using waste non edible seeds could also help to solve the problem of waste seeds disposal [18]. Most current biodiesel research concentrates on the alkali-catalyzed technology carried out on a bench scale and no detailed technological information is available on overall continuous industrial processes in which both reactor and downstream separation units are continuously operated. Information on industrial process simulation and design is also unavailable. Apart from the transesterification reaction, the actual process of biodiesel production includes many process steps from raw material refining to product separation and purification. Evaluating the technological and economic feasibility of a biodiesel plant involves all operating units, not only one reactor. So there is a need to design a complete continuous process and assess its performance from the viewpoint of an entire plant. Therefore, an experimental study on biodiesel production from karanja (Pongamia pinnata) oil was undertaken.

\section{Experimental}

Materials: Karanja (Pongamia pinnata) seeds was used as raw material to produce biodiesel. Seeds was collected from rural area of the country. Methanol $\left(\mathrm{CH}_{3} \mathrm{OH}\right)$ was used in the trans-esterification reaction which was 98\% pure. $\mathrm{NaOH}$ and $\mathrm{H}_{2} \mathrm{SO}_{4}$ were used as catalyst which was purchased from local market.
Some other reagents such as iso-propanol, $\mathrm{NaOH}$ solution, titration solvent (Toluene+Iso-propanol), bromine water, barium chloride, $\mathrm{HCl}$, were used for the production and analysis of biodiesel.

Methods: Collected karanja seeds was primarily grinded. The oil was extracted from Karanja seeds by solvent extraction method and yield of oil was obtained about $40 \%$. Free fatty acid content of the raw material was measured via acid value determination. Acid value was determined by a standard acid base titration method (IP-1/58) where a standard solution of $1 \mathrm{M} \mathrm{KOH}$ was used. Due to low free fatty acid (Less than 5\% FFA), the karanja oil was processed with Base-catalyzed transesterification [2]. Transesterification process converted karanja oil into biodiesel and glycerol using $1 \% \mathrm{w} / \mathrm{w} \mathrm{NaOH}$ as alkaline catalyst at $60-65^{\circ} \mathrm{C}$.After purification, the various properties of the produced biodiesel were determined by several ISO standard methods [19][20].

\section{Results and Discussion}

\section{Transesterification Process Optimization:}

Effect of change of molar ratio of limiting reactants (methanol)

\section{i) Biodiesel production in small scale}

Transesterification was carried out in small scale with the help of $20 \mathrm{ml}$ measured small scale tube with stirrer. The amount of catalyst $(\mathrm{NaOH})$ was kept fixed $1 \%$ of Karanja oil.

Table. 1. The effect of variation of oil to methanol ratio on product yield

\begin{tabular}{|c|c|c|c|c|c|}
\hline Exp. no. & $\begin{array}{c}\text { Wt. of } \\
\text { methanol (mg) }\end{array}$ & $\begin{array}{l}\text { Wt. of Karanja oil } \\
(\mathrm{mg})\end{array}$ & $\begin{array}{c}\text { Wt. } \\
\text { of catalyst } \\
(\%)\end{array}$ & $\begin{array}{c}\text { Oil to } \\
\text { methanol ratio }\end{array}$ & $\%$ Yield \\
\hline Exp. no-1 & 163 & 970 & \multirow{6}{*}{1} & $6: 1$ & 64 \\
\hline Exp. no-2 & 145 & 995 & & $7: 1$ & 71 \\
\hline Exp. no-3 & 124 & 987 & & $8: 1$ & 74 \\
\hline Exp. no-4 & 110 & 988 & & $9: 1$ & 85 \\
\hline Exp. no-5 & 102 & 995 & & $10: 1$ & 80 \\
\hline Exp. no-6 & 91 & 992 & & $11: 1$ & 77 \\
\hline
\end{tabular}

From the Table-1, it was found that with the increase of molar ratio, the yield of biodiesel increased up to $85 \%$, when molar ratio was 9:1. Again with the increase of molar ratio, the yield decreased. Catalyst $(\mathrm{NaOH})$ was kept fixed $1 \%$ of karanja (Pongamia pinnata) oil for above experiments to get optimum yield. 


\section{ii) Biodiesel production in large scale}

Table. 2. The effect of variation karanja oil to methanol ratio on product yield

\begin{tabular}{|c|c|c|c|c|c|}
\hline $\begin{array}{c}\text { Experiment } \\
\text { No: }\end{array}$ & $\begin{array}{l}\text { Wt. of methanol } \\
(\mathrm{g})\end{array}$ & $\begin{array}{l}\text { Wt. of karanja } \\
\text { oil }(\mathrm{g})\end{array}$ & $\begin{array}{c}\text { Wt. of catalyst } \\
(\%)\end{array}$ & Oil to methanol ratio & $\%$ Yield \\
\hline No-1 & 16.58 & 100 & \multirow{6}{*}{1} & $6: 1$ & 66 \\
\hline No-2 & 14.30 & 100 & & $7: 1$ & 71 \\
\hline No-3 & 12.50 & 100 & & $8: 1$ & 79 \\
\hline No-4 & 11.12 & 100 & & $9: 1$ & 86 \\
\hline No-5 & 10.00 & 100 & & $10: 1$ & 81 \\
\hline No-6 & 9.10 & 100 & & $11: 1$ & 78 \\
\hline
\end{tabular}

From the Table-2, it was found that with the increase of molar ratio of Karanja oil to methanol, the yield biodiesel increase up to $86 \%$, when molar ratio was 9:1. Again with the increase of molar ratio, the yield decrease. Catalyst $(\mathrm{NaOH})$ was kept fixed $1 \%$ of karanja oil for above experiments to get optimum yield.

\section{Effect of change of catalyst concentration}

\section{i) Biodiesel production in small scale}

Table. 3. Variation of catalyst concentration with constant wt. of oil and methanol

\begin{tabular}{|c|c|c|c|c|}
\hline Exp no. & Wt. of methanol(mg) & $\begin{array}{l}\text { Wt. of Karanja oil } \\
(\mathrm{mg})\end{array}$ & $\begin{array}{c}\text { Wt. of catalyst } \\
(\%)\end{array}$ & $\%$ Yield \\
\hline Exp. no-1 & \multirow{6}{*}{112} & 1000 & 0.5 & 40 \\
\hline Exp. no-2 & & 1000 & 0.8 & 68 \\
\hline Exp. no-3 & & 1000 & 1.0 & 82 \\
\hline Exp. no-4 & & 1000 & 1.2 & 78 \\
\hline Exp. no-5 & & 1000 & 1.4 & 45 \\
\hline Exp. no-6 & & 1000 & 1.6 & 20 \\
\hline
\end{tabular}

From the Table-3, it was found that with the increase of catalyst concentration, yield of biodiesel increase up to $82 \%$, when wt. of catalyst $1 \%$ of Karanja oil. Again with the increase of catalyst concentration, the yield decreased. Methanol was kept fixed. Molar ratio of karanja oil to methanol was 9:1

\section{ii) Biodiesel production in large scale}

Table. 4. Variation of catalyst concentration with constant wt. of oil and methanol.

\begin{tabular}{|c|c|c|c|c|}
\hline $\begin{array}{c}\text { Experiment } \\
\text { No. }\end{array}$ & Wt. of methanol(g) & Wt. of Karanja oil (g) & $\begin{array}{c}\text { Wt. of catalyst } \\
(\%)\end{array}$ & $\%$ Yield \\
\hline No-1 & \multirow{4}{*}{11.2} & 100 & 0.5 & 40 \\
\hline No-2 & 100 & 0.8 & 74 \\
\hline No-3 & 100 & 1.0 & 81 \\
\hline No-4 & & 100 & 1.2 & 76 \\
\hline No-5 & & 100 & 1.5 & 65 \\
\hline No-6 & & 100 & 1.6 & 25 \\
\hline
\end{tabular}

From the Table-4, it is found that with the increase of catalyst concentration, the yield biodiesel increased up to $81 \%$, when wt. of catalyst $1 \%$ of karanja oil. Again with the increase of catalyst concentration, the yield decreased.
Methanol was kept fixed. Molar ratio of karanja oil to methanol was 9:1 for above experiments.

Thus, the optimum condition for the production of biodiesel from karanja oil are- 
Molar ratio of biodiesel to methanol is 9:1 and amount of catalyst $(\mathrm{NaOH})$ concentration is $1 \%$ of the oil.

\section{Properties of biodiesel}

The properties of the produced biodiesel that were determined are presented in the following (Table-5) in comparison with the commercial diesel.

Table. 5. Comparison of obtained biodiesel \& commercial diesel [19] [20].

\begin{tabular}{|c|c|c|c|}
\hline Name of the analysis & Method & Biodiesel & Commercial diesel \\
\hline Density at $15^{\circ} \mathrm{C}$ & IP-160/57 & 0.875 & 0.8445 \\
\hline Kinematic viscosity @ $40^{\circ} \mathrm{C}, \mathrm{cSt}$ & D 445-65 & 38.53 & 6.06 \\
\hline Pour point, ${ }^{\circ} \mathrm{C}$ & D $97-57$ & -4 & -2 \\
\hline Flash point, ${ }^{0} \mathrm{C}$ & D 93-62 & 158 & 70 \\
\hline Acid value, $\mathrm{mg} \mathrm{KOH} / \mathrm{g}$ & IP-1/58 & 0.423 & 0.34 \\
\hline Sulfur content, \%mass & D $129-64$ & 0.024 & 0.905 \\
\hline Cetane no. & D $613-86$ & 58.22 & 51 \\
\hline Water content, \% & IP-74/57 & Trace Amount & Zero \\
\hline Carbon residue, $\%$ & D $189-65$ & 0.39 & - \\
\hline Ash content, $\%$ & D $482-63$ & 0.003 & - \\
\hline
\end{tabular}

Co-ignition characteristics test of karanja oil diesel with commercial diesel

Diesel oil was collected from local market and coignition characteristics [14] was observed using different ratio with karanja oil derived biodiesel. Results of different experiments of co-ignition are shown in the Table-6. It was found that diesel engine run more smoothly in the ratio of commercial diesel to biodiesel $7: 3$ and gives best engine performance.

Table. 6. Co-ignition characteristics of karanja oil derived biodiesel with commercial diesel

\begin{tabular}{|l|c|c|c|c|}
\hline Type & Ratio & Duration, min & $\begin{array}{c}\text { Load } \\
\text { Applied(KW) }\end{array}$ & Observation \\
\hline $\begin{array}{l}\text { Conventional diesel to } \\
\text { karanja oil biodiesel }\end{array}$ & $9: 1$ & $12 \mathrm{mins}$ & 2130 & Running smoothly \\
\hline $\begin{array}{l}\text { Conventional diesel to } \\
\text { karanja biodiesel }\end{array}$ & $8: 2$ & $11 \mathrm{mins}$ & 2130 & Running more smoothly. \\
\hline $\begin{array}{l}\text { Conventional diesel to } \\
\text { karanja oil biodiesel }\end{array}$ & $7: 3$ & $12 \mathrm{mins} 30 \mathrm{sec}$ & 2130 & Running smoothly \\
\hline $\begin{array}{l}\text { Conventional diesel to } \\
\text { karanja oil biodiesel }\end{array}$ & $6: 4$ & $10 \mathrm{mins} 25 \mathrm{sec}$ & 2130 & Running smoothly \\
\hline $\begin{array}{l}\text { Conventional diesel to } \\
\text { karanja oil biodiesel }\end{array}$ & $5: 5$ & $9 \mathrm{mins} 32 \mathrm{sec}$ & 2130 & Running smoothly \\
\hline Conventional diesel & $100 \%$ & $11 \mathrm{mins} 28 \mathrm{sec}$ & 2130 & Running smoothly with bad smell \\
\hline karanja oil biodiesel & $100 \%$ & $8 \mathrm{mins} 10 \mathrm{sec}$ & 2130 & \\
\hline
\end{tabular}

\section{Conclusion}

In this research work, biodiesel was produced from waste karanja oil. Co-ignition characteristics of karanja oil derived biodiesel with commercial diesel were observed. Diesel engine runs more smoothly in the ratio of commercial diesel to karanja oil biodiesel was 7:3. The properties of the produced biodiesel have been studied and were compared with the commercial diesel and found to be reasonable. The properties of produced biodiesel were comparable to that of commercial diesel and it can be used as substitute of petro diesel to save foreign exchange and control environmental pollutions to a some extent.

\section{Acknowledgements}

The research work was carried out in cooperation with Institute of Fuel Research and Development (IFRD), Bangladesh Council of Scientific \& Industrial Research (BCSIR), Dhaka-1205, Bangladesh. The authors are grateful to all the officers and staffs of IFRD for their cordial help and support throughout the works. 
1. A.Brucato,A.Busciglio, F.Di Stefano, F.Grisafi, G.Micale, F.Scargiali (2010) High temperature solidcatalyzed transesterification for biodiesel production. CHEMICAL ENGINEERING TRANSACTIONS 19 : 31-36

2. Yusup, Suzana and Khan, Modhar (2010) Base catalyzed transesterification of acid treated vegetable oil blend for biodiesel production. Biomass and Bioenergy, 34 (10). pp. 1500-1504. ISSN 0961-9534

3. Agarwal A.K. and L.M. Das (2001) Biodiesel development and characterization for use as a fuel in compression ignition engines. J. Eng. Gas Turbines Power 123(3): 440-447

4. Azam M.M., A. Waris and N.M. Nahar (2005) Prospects and potential of fatty acid methyl esters of some nontraditional seed oils for use as biodiesel in India. Biomass and Bioenergy 29 (1): 293-302

5. Berchmans T., H.Johannes and K.Shizuko (2008) Biodiesel production from crude Jatropha curcas L. seed oil with a high content of free fatty acids. Bioresource Technology, 99(6): 1716-1721

6. Connemann J. and J. Fischer (1998) Biodiesel in Europe 1998: Biodiesel processing technologies. Paper presented at the International Liquid Biofuels Congress, Brazil, 1998, pp 15

7. De B.K. and D.K.Bhattacharyya (1999) Biodiesel from minor vegetable oils like karanja oil and nahor oil. LipidFett J., 101(1): 404-406

8. Karmee S.J. and A. Chadha (2005) Preparation of biodiesel from crude oil of Pongamia pinnata. Bioresource Technology 96(4): 1425-1429

9. Korbitz W. (1999) Biodiesel production in Europe and North American, an encouraging prospect. Renew. Energy J., 16(2): 1078-1083
10. Krawczyk T. (1996) Biodiesel. INFORM 7 (8), 801-822. Kreutzer, U.R., 1984. Manufacture of fatty alcohols based on natural fats and oils. J. Am. Oil Soc. Chem. 61(2): 343-348

11. Lott M. (2002). QSS Group Inc., 4500 Forbes Boulevard, Suite 200, Lanham, 2002, pp 207

12. Nelson L.A., T.A. Foglia and W.N. Marmer (1996) Lipasecatalyzed production of biodiesel. J. Am. Oil Soc. Chem. 73(8): 1191-1195

13. Prokop T. (2002) Imperial Western Products, 14970 Chandler St., Coachella, 2002, pp 91

14. Raheman H, and A.G Phadatare. (2004) Diesel engine emissions and performance from blends of karanja methyl ester and diesel. Biomass and Bioenergy 27(5): 393-397

15. Supple B., R. Howard-Hildige, E. Gonzalez-Gomez and J.J. Leahy (1999) The effect of steam treating waste cooking oil on the yield of methyl ester. J. Am. Oil Soc. Chem. 79(2): 175-178

16. Von Wedel R. (1999) Technical handbook for marine biodiesel in recreational boats. Prepared for National Renewable Energy Laboratory, US Department of Energy, 1999, pp 32

17. Watanabe Y., Y Shimada., A. Sugihara and Y. Tominaga (2001) Enzymatic conversion of waste edible oil to biodiesel fuel in a fixed-bed bioreactor. J. Am. Oil Soc. Chem. 78(2): 703-707

18. Wiltsee G. (1998) Waste grease resource in 30 US metropolitan areas. In: The Proceedings of Bioenergy 98 Conference, Wisconsin (USA), 1998, pp 956-963

19. Saiful Islam M., M.S. Jamal, S.M.A.Sujan, M. Ismail, M.Yunus Miah, M.Saha (2011) Bio-Oil From Pyrolysis of Rice Husk. Journal of Biofuels ,V (2), pp.1-7.

20. Arafat H. Khan, M.Saiful Islam, H.M.Imran, M.Yunus Miah and Rafiqul Islam (2011) Study of the Thermal Cracking of Used Lubricating Oil to produce Gasoline. DUJASE 2(1) 3943, 2011 (July) 